\title{
An observation of an unusual human-directed threat display by Sapajus cay Illiger, 1815 (Cebidae: Primates) in a fragment of Upper Paraná Atlantic Forest, eastern Paraguay
}

\author{
Rebecca L. Smith \\ Fundación Para La Tierra, Rancho Laguna Blanca, Departamento San Pedro, Paraguay. rebecca@paralatierra.org
}

The response of wild primates to potential predators is dependent on the level of threat that is perceived (De A. Moura, 2007; Papworth et al., 2013). Primates often react to the presence of predators with intimidation displays and many species incorporate objects from their environment into their displays (Beck, 1980). In capuchin monkeys (Cebus and Sapajus species) displays involving branch shaking and breaking branches to throw or drop on predators are well-documented (Oppenheimer \& Oppenheimer, 1973; Beck, 1980; Chevalier-Skolnikoff, 1990; Panger, 1998; Fragaszy et al., 2004). Capuchins have also been recorded banging rocks as an auditory anti-predator display (De A. Moura, 2007) and Boinski et al. (1988) reported a male white-faced capuchin (Cebus capucinus) killing a venomous snake with a branch. Here I report on an observation of an unusual threat display involving fur-rubbing with Citrus sp. leaves by an adult male hooded capuchin (Sapajus cay) in the Upper Paraná Atlantic Forest fragment of Rancho Laguna Blanca in eastern Paraguay.

Rancho Laguna Blanca, San Pedro, Paraguay ( $23^{\circ} 4952.0^{\prime \prime}$ S 56 $17^{\prime} 42.2^{\prime \prime} \mathrm{W}$ ) is an 804-ha reserve, located in the transitional zone between the Cerrado and Atlantic Forest ecoregions. The reserve contains a small fragment of 243 ha of young secondary Upper Paraná Atlantic Forest, characterized by deciduous, mesophytic, broadleaf plants (Lowen et al., 1996). The fragment is home to two groups (O and F) of Hooded capuchins. O Group consists of 19 individuals and F Group consists of 15-16 individuals. Habituation of the two groups began in 2012 but the history of hunting in the area has made the capuchins extremely wary of humans. When approached the capuchins of both groups normally respond with loud alarm calls, fear grimacing and threat faces, branch shaking and dropping branches on observers, though the $\mathrm{O}$ Group capuchins are far more tolerant of human presence (Smith pers. obs.).

On October 20, 2014, at 07:50, F Group was encountered foraging close to the ground ( $23^{\circ} 49.719^{\prime} \mathrm{S} 056^{\circ} 17.593^{\prime} \mathrm{W} .209$ $\mathrm{m})$. At the approach of the observer all the adults began to alarm call loudly and the majority of the capuchin fled north, deeper into the forest. One adult male remained in a Citrus sp. tree, approximately $7 \mathrm{~m}$ high and $10 \mathrm{~m}$ from the observer. The male performed an elaborate threat display involving branch shaking, vigorous head bobbing, fear grimacing and alarm calling. He then stood bipedally and jumped up and down three times before leaning forward and ripping a large handful of leaves. While continuing to stand bipedally and fear grimace at the observer he began to rub the leaves into the fur on his chest and stomach. Crouching low to the branch he proceeded to rub the leaves into the fur of his legs and arms while alarm calling. This display continued for almost a full minute before he threw the leave into the air and fled in the same direction as the rest of F Group.

Fur-rubbing (or anointing) is a behaviour in which an individual monkey applies a substance, most commonly plant material or invertebrates such as ants or millipedes, to its fur using the hands and tail (Fragaszy et al., 2004). Fur-rubbing is hypothesised to be a form of self-medication and experimental evidence indicates that this behaviour is effective in reducing the parasite diversity and loads in capuchin monkeys (Hart, 1997). The use of Citrus plant materials in anointing is well documented in Cebus species but has not been observed in wild Sapajus species (Buckley, 1983; Perry, 1996; Panger, 1998; Baker et al., 1999; Lynch-Alfaro et al., 2011). The leaves of Citrus trees have a pungent odour and have been used by native people to treat skin irritations and as an insect repellent (Costa-Neto, 2012).

This is the only time that fur-rubbing has been observed in the hooded capuchins of Rancho Laguna Blanca and further investigation is required to determine whether this behaviour occurs in a social or self-medication context as well as this intimidation display. To the best of my knowledge, the use of fur-rubbing has not been documented as part of an intimidation display in wild Sapajus species and this is the first documentation of fur-rubbing behaviour in wild Sapajus cay.

\footnotetext{
Mammalogy Notes | Notas Mastozoológicas

Sociedad Colombiana de Mastozoología

Vol. 4 Num. 1| 2017
} 


\section{Acknowledgements}

Thanks to Paul Smith, the SEAM and Malvina Duarte.

\section{References}

BAKER, M.E. 1999. Fur rubbing as evidence for medicinal plant use by capuchin monkeys (Cebus capucinus): ecological, social and cognitive aspects of the behaviour. Dissertation Abstracts International. 3870.

BECK, B.B 1980. Animal Tool Behaviour: The Use and Manufacture of Tools by Animals. Garland Press, New York.

BOINSKI, S. 1988. Use of a club by a wild white-faced capuchin (Cebus capucinus) to attack a venomous snake (Bothrops asper). American Journal of Primatology. 14: 177-179.

BUCKLEY, J.S. 1983. The feeding behaviour, social behaviour and ecology of the white-faced monkey, Cebus capcuinus, at Trujillo, Northern Honduras, Central America. Dissertation Abstracts International. 1143.

CHEVALIER-SKOLNIKOFF, S. 1990. Tool use by wild Cebus monkeys at Santa Rosa National Park, Costa Rica. Primates. 31: 375-383.

COSTA-NETO, E. M. 2012. Zoopharmacognosy: The self-medication behaviour of animals. Interfaces Científicas. 1: 61-72.

DE A. MOURA, A.C. 2007. Stone banging by wild Capuchin Monkeys: An unusual auditory display. Folia Primatologia. 78: 36-45.

FRAGASZY, D. M et al 2004. The Complete Capuchin. Cambridge University Press, Cambridge.

HART, B.L. 1997. Behavioural defence: In Clayton DH, Moore JC (eds). Host Parasite Evolution: General principles and avian models. Oxford University Press, Oxford.

LYNCH ALFARO, J. W. et al. 2011. Anointing variation across wild capuchin populations: A review of material preferences, bout frequency and anointing sociality in Cebus and Sapajus. American Journal of Primatology. 73: 1-16.

LYNCH ALFARO, J. W. et al. 2013. Capuchin monkey research priorities and urgent issues. American Journal of Primatology.

PAPWORTH, S. et al. 2013. Hunted woolly monkeys (Lagotrhix poeppigii) show threat-sensitive responses to human presence. PLOS One. 8: 1-11.

PANGER, MA et al. 1998. Object-use in free-ranging white-faced capuchins (Cebus capucinus) in Costa Rica. American Journal of Physical Anthropology. 106: 311-321.

PERRY, S. E. 1996. Social relationships in wild white-faced capuchin monkeys, Cebus capucinus. Dissertation Abstracts International. 3194.

OPPENHEIMER, J.R \& E.C. OPPENHEIMER 1973. Preliminary observations of Cebus nigrivittatus (Primates: Cebidae) on the Venezuelan Llanos. Folia Primatologia. 19: 409-436. 